\title{
Article \\ Genetic Diversity of Castor Bean (Ricinus communis L.) Revealed by ISSR and RAPD Markers
}

\author{
HyokChol Kim ${ }^{1}$, Pei Lei ${ }^{1}$, Aizhi Wang ${ }^{1}$, Shuo Liu ${ }^{1}$, Yong Zhao ${ }^{2,3}$, Fenglan Huang ${ }^{2,3, *}$, Zhenliang Yu ${ }^{4}$, \\ Guoli Zhu ${ }^{5}$, Zhibiao He ${ }^{5}$, Deyun Tan ${ }^{6}$, Hongwei Wang ${ }^{7}$ and Fanjuan Meng ${ }^{1, *}$ \\ 1 College of Life Science, Northeast Forestry University, Harbin 150040, China; 15104601275@163.com (H.K.); \\ 18800465845@163.com (P.L.); mfj19751@163.com (A.W.); 1s977573@163.com (S.L.) \\ 2 College of Life Science, Inner Mongolia University for the Nationalities, Tongliao 028043, China; \\ 15334946958@163.com \\ 3 Inner Mongolia Key Laboratory of Castor Breeding, Tongliao 028043, China \\ 4 Heilongjiang Provincial Hydraulic Research Institute, Harbin 150080, China; yzl56123@163.com \\ 5 Tongliao Academy of Agricultural Science, Tongliao 028000, China; 18800465846@163.com (G.Z.); \\ hezhibiao@139.com (Z.H.) \\ 6 Academy of Agricultural Sciences, Zibo 255000, China; tandeyun@126.com \\ 7 Shanxi Academy of Agricultural Sciences, Fenyan 032200, China; jzswhw@163.com \\ * Correspondence: huangfenglan@imun.edu.cn (F.H.); m13313626779@163.com (F.M.)
}

Citation: Kim, H.; Lei, P.; Wang, A.; Liu, S.; Zhao, Y.; Huang, F.; Yu, Z.;

Zhu, G.; He, Z.; Tan, D.; et al. Genetic Diversity of Castor Bean (Ricinus communis L.) Revealed by ISSR and RAPD Markers. Agronomy 2021, 11, 457. https://doi.org/10.3390/ agronomy11030457

Academic Editor: J. Stephen C Smith

Received: 27 January 2021

Accepted: 24 February 2021

Published: 1 March 2021

Publisher's Note: MDPI stays neutral with regard to jurisdictional claims in published maps and institutional affiliations.

Copyright: (c) 2021 by the authors. Licensee MDPI, Basel, Switzerland. This article is an open access article distributed under the terms and conditions of the Creative Commons Attribution (CC BY) license (https:/ / creativecommons.org/licenses/by/ $4.0 /)$.

\begin{abstract}
Castor (Ricinus communis L.), known as castor oil plant or castor bean, is a non-edible oilseed crop. In the present study, the genetic diversity among 54 samples ( 3 wild and 51 cultivated) collected worldwide was evaluated using inter-simple sequence repeats (ISSRs) and random amplified polymorphic DNA (RAPD) markers. A total of 9 ISSR primers produced 83 high-resolution bands with $61(74.53 \%)$ as polymorphic. The percentage of polymorphic bands per primer and the genetic similarity coefficient ranged from $54.55 \%$ (UBC-836) to $100 \%$ (UBC-808) and from 0.74 to 0.96 , respectively. A total of 11 out of 20 RAPD primers amplified unique polymorphic products with an average percentage of polymorphic bands of $60.98 \%$ (56 polymorphic bands out of a total of 90 bands obtained). The percentage of polymorphic bands per primer ranged from $25 \%$ (OPA-02 and B7) to $90.91 \%$ (B21) with the genetic similarity coefficient ranging from 0.73 to 0.98 . The unweighted pair group method with arithmetic averages (UPGMA) dendrogram using two molecular markers divided 54 castor genotypes into three groups. Furthermore, based on morphological data, all 54 castor varieties were grouped into three main clusters. The genetic diversity analysis based on two molecular makers showed that most varieties from China were closely related to each other with three varieties (GUANGDONGwild, ZHEJIANGWild, and HANNANWild) belonging to a wild group separated from most of the cultivated castor samples from China, India, France, and Jordan. These results suggested that the cultivated castor contains a narrow genetic base. Accordingly, we recommend that wild castor genetic resources be introduced for breeding novel castor varieties. Furthermore, the Vietnam, Malaysia, Indonesia, and Nigeria accessions were clustered into the same group. The results of principal coordinate analysis (PCOA) and UPGMA cluster analysis were consistent with each other. The findings of this study are important for future breeding studies of castor.
\end{abstract}

Keywords: Ricinus communis L.; genetic diversity; inter simple sequence repeat (ISSR); random amplified polymorphic DNA (RAPD)

\section{Introduction}

Castor (Ricinus communis L.) is an annual or perennial plant in Euphorbiaceae and is indigenous to the southeastern Mediterranean basin, East Africa, and India [1]. The castor is known to be highly tolerant in drought [2,3] and its leaves can be used as the food of silkworm. In addition, castor bean with an oil content of $45-55 \%$ in the seeds is considered 
as one of the top 10 oil crops worldwide [4,5]. Castor oil is the non-drying oil with high viscosity and is not easily clogged even under a low temperature of $-56^{\circ} \mathrm{C}$ [6]. Therefore, castor oil can be used for the production of biofuel in the chemical industry $[7,8]$. The demand for castor products such as castor oil and its derivatives has increased worldwide since 1991 [9-11]. After 2014, the import rate of castor raw materials in China has increased over $90 \%[10,12]$. To date, many methods or techniques have already been used to improve breeding and productivity of castor [13-16].

Analyses of genetic diversity are very important for the development of genetic resources and new varieties of castor. In the past, genetic diversity studies based on morphological and biochemical characteristics have been conducted in many animal and plant varieties $[17,18]$. In particular, morphological traits are important phenotypic indicators in the development of sustainable crop breeding [19]. However, the study of genetic diversity based only on the morphological and geographical characteristics is ineffective, due to the strong influence of environmental complexity and genetic responses of plants. To date, many stable and efficient molecular markers have been developed. For example, studies of genetic diversity using molecular markers, such as simple sequence repeat (SSR), amplified fragment length polymorphism (AFLP), restriction fragment length polymorphism (RFLP), and single nucleotide polymorphisms (SNPs) have been widely applied in castor [20,21]. However, these methods have shown some disadvantages such as the high cost of AFLP and radioactive labeling of RFLP [22,23]. In recent years, developing SSR markers through mining SSR motifs in the whole genome has reduced the cost greatly, but has shown somewhat lower congruence with dominant marker data [24,25]. Both random amplified polymorphic DNA (RAPD) and inter-simple sequence repeats (ISSRs) have been used to study the genetic diversity and evaluate the genetic mutations of many plants $[26,27]$. ISSR technologies were found to be reproducible and effective to uncover polymorphism and obtain more composite marker patterns [28,29]. In contrast, RAPD has low rate of replicability, but is very efficient in analyzing genetic diversity because it does not need sequence data to design molecular primers [30,31].

Generally, both ISSR and RAPD markers are used in combination to improve their resolving power for genetic analysis of many plants [32]. In the past decade, combined morphological and molecular analyses have been widely used to investigate genetic diversity and phylogenetic relationships. For example, morphological characters and RAPD were demonstrated useful for reconstructing a Citrus phylogeny [33] and morphological traits and both RAPD and ISSR markers were evaluated to discriminate 15 potato cultivars [34] and to establish unique identification profiles in 26 sorghum varieties [35].

To obtain data of high quality, the study of genetic diversity based on both morphological characters and molecular markers (i.e., RAPD and ISSRs) is very important for castor breeding and production. To date, there are only a few studies available on analyzing the genetic variation by using combined RAPD and ISSR markers and morphometric characters. In this study, we aim to resolve the relationship between wild and cultivated varieties of caster from different accessions collected worldwide. These results provide the basic information for cultivating new varieties of caster and contribute to the selection and verification of novel varieties and the preservation of castor germplasms.

\section{Materials and Methods}

\subsection{Plant Materials}

The seeds of 54 castor varieties from different regions of the world were provided by the Inner Mongolia Key Laboratory of Castor Breeding, China. During the experiment, four quantitative traits (seed length $(\mathrm{mm})$, width $(\mathrm{mm})$, thickness $(\mathrm{mm})$, and weight $(\mathrm{g})$ ) were measured on ten random samples. Detailed information on these 54 accessions is showed in Table 1 and Figure 1. Seed coat colors were scored by comparison with standards by multiple observers. 
Table 1. List of the castor beans (R. communis L.) included in the work.

\begin{tabular}{|c|c|c|c|c|c|c|c|}
\hline No. & Variety & Location & Length (mm) & Width (mm) & L/W Ratio & $\begin{array}{l}\text { Thickness } \\
\text { (mm) }\end{array}$ & Weight (g) \\
\hline 1 & GUANGDONGWild & $\begin{array}{l}\text { Guangdong } \\
\text { (China) }\end{array}$ & $10.24 \pm 0.52^{f}$ & $6.60 \pm 0.19 \mathrm{de}$ & $1.55 \pm 0.04^{b c}$ & $4.96 \pm 0.18$ & $0.19 \pm 0.02 \mathrm{de}$ \\
\hline 2 & ZHEJIANGWild & Zhejiang (China) & $10.44 \pm 0.33^{f}$ & $6.46 \pm 0.17^{\mathrm{e}}$ & $1.62 \pm 0.03^{b}$ & $4.97 \pm 0.19$ de & $0.16 \pm 0.01 \mathrm{de}$ \\
\hline 3 & HAINANWild & Hainan (China) & $9.85 \pm 0.15^{g}$ & $5.97 \pm 0.03^{\mathrm{e}}$ & $1.65 \pm 0.03^{\mathrm{ab}}$ & $4.26 \pm 0.09^{\mathrm{e}}$ & $0.13 \pm 0.01^{\mathrm{e}}$ \\
\hline 4 & Lubri & India & $13.12 \pm 0.78^{\mathrm{cd}}$ & $8.32 \pm 0.53^{c}$ & $1.58 \pm 0.11^{b c}$ & $6.08 \pm 0.29 b c$ & $0.36 \pm 0.05^{\mathrm{cd}}$ \\
\hline 5 & SANGRAM9 & India & $13.15 \pm 0.51^{\mathrm{cd}}$ & $8.25 \pm 0.26^{c}$ & $1.59 \pm 0.55^{b c}$ & $6.13 \pm 0.26^{b c}$ & $0.35 \pm 0.03^{\mathrm{cd}}$ \\
\hline 6 & HYCASTOR & India & $12.56 \pm 0.28^{\mathrm{cd}}$ & $8.76 \pm 0.08^{b c}$ & $1.43 \pm 0.02^{\mathrm{d}}$ & $6.34 \pm 0.15^{b c}$ & $0.37 \pm 0.03^{\mathrm{cd}}$ \\
\hline 7 & CSR.181 & France & $14.10 \pm 0.21^{\mathrm{c}}$ & $8.17 \pm 0.32^{c}$ & $1.73 \pm 0.03^{\mathrm{a}}$ & $6.38 \pm 0.31^{b c}$ & $0.35 \pm 0.02^{\mathrm{cd}}$ \\
\hline 8 & CSR.63 & France & $12.32 \pm 0.28^{\mathrm{d}}$ & $8.29 \pm 0.17^{c}$ & $1.49 \pm 0.03^{\mathrm{cd}}$ & $5.99 \pm 0.16^{c}$ & $0.32 \pm 0.03^{d}$ \\
\hline 9 & Middle East Castor & Jordan & $14.53 \pm 0.57 \mathrm{bc}$ & $8.83 \pm 0.26^{b c}$ & $1.65 \pm 0.03^{a b}$ & $6.53 \pm 0.11^{b}$ & $0.39 \pm 0.02^{\mathrm{cd}}$ \\
\hline 10 & A063 & $\mathrm{CAOF}$ & $12.13 \pm 0.28^{\mathrm{d}}$ & $8.09 \pm 0.15^{c}$ & $1.50 \pm 0.02^{\mathrm{c}}$ & $5.83 \pm 0.09^{c}$ & $0.25 \pm 0.04^{\mathrm{d}}$ \\
\hline 11 & YUNbima5 & Yunnan (China) & $14.21 \pm 0.58^{c}$ & $9.32 \pm 0.69 b c$ & $1.52 \pm 0.15^{c}$ & $6.49 \pm 0.30 \mathrm{bc}$ & $0.45 \pm 0.02^{c}$ \\
\hline 12 & YUNbima4 & Yunnan (China) & $14.99 \pm 0.72 \mathrm{bc}$ & $10.49 \pm 0.31^{b}$ & $1.43 \pm 0.10^{\mathrm{d}}$ & $6.99 \pm 0.28^{b}$ & $0.55 \pm 0.02^{b}$ \\
\hline 13 & SHANXIbima & Shanxi (China) & $14.31 \pm 0.34^{\mathrm{c}}$ & $9.08 \pm 0.27 b c$ & $1.58 \pm 0.01^{\mathrm{bc}}$ & $6.65 \pm 0.10^{b}$ & $0.42 \pm 0.07^{c}$ \\
\hline 14 & zhebima3 & Tongliao (China) & $12.20 \pm 0.46^{\mathrm{d}}$ & $7.96 \pm 0.39 \mathrm{~cd}$ & $1.53 \pm 0.05^{c}$ & $5.91 \pm 0.30^{c}$ & $0.30 \pm 0.04^{\mathrm{d}}$ \\
\hline 15 & zhebima4 & Tongliao (China) & $12.42 \pm 0.51^{\mathrm{d}}$ & $8.20 \pm 0.09^{c}$ & $1.51 \pm 0.05^{c}$ & $6.78 \pm 0.28^{b}$ & $0.31 \pm 0.03^{\mathrm{d}}$ \\
\hline 16 & Tongbima5 & Tongliao (China) & $13.13 \pm 0.76^{\mathrm{cd}}$ & $8.12 \pm 0.91^{c}$ & $1.62 \pm 0.26^{\mathrm{b}}$ & $6.16 \pm 0.52^{b c}$ & $0.32 \pm 0.04^{\mathrm{d}}$ \\
\hline 17 & Tongbima5 & Tongliao (China) & $11.60 \pm 0.42^{\mathrm{e}}$ & $7.88 \pm 0.31^{\mathrm{cd}}$ & $1.47 \pm 0.04^{\mathrm{cd}}$ & $5.73 \pm 0.33^{c}$ & $0.27 \pm 0.03^{\mathrm{d}}$ \\
\hline 18 & Tongbima8 & Tongliao (China) & $12.84 \pm 0.56^{\mathrm{cd}}$ & $8.46 \pm 0.37^{c}$ & $1.52 \pm 0.10^{c}$ & $6.47 \pm 0.25^{b c}$ & $0.34 \pm 0.06^{\mathrm{cd}}$ \\
\hline 19 & Tongbima9 & Tongliao & $13.23 \pm 0.58^{\mathrm{cd}}$ & $8.09 \pm 0.49^{c}$ & $1.64 \pm 0.04^{\mathrm{b}}$ & $6.13 \pm 0.26^{b c}$ & $0.32 \pm 0.06^{\mathrm{d}}$ \\
\hline 20 & Tongbima10 & Tongliao (China) & $12.31 \pm 0.37^{\mathrm{d}}$ & $8.59 \pm 0.29 b c$ & $1.43 \pm 0.02^{\mathrm{d}}$ & $6.29 \pm 0.25^{b c}$ & $0.33 \pm 0.04^{\mathrm{d}}$ \\
\hline 21 & ZHE10 & Shanxi (China) & $14.14 \pm 0.3$ & $8.80 \pm 0.41^{b c}$ & $1.61 \pm 0.10^{\mathrm{b}}$ & $6.07 \pm 0.21^{b c}$ & $0.36 \pm 0.04^{\mathrm{cd}}$ \\
\hline 22 & SL42-30 & Shanxi (China) & $12.47 \pm 0.34^{\mathrm{d}}$ & $8.83 \pm 0.16^{b c}$ & $1.41 \pm 0.04^{\mathrm{d}}$ & $6.20 \pm 0.25 \mathrm{bc}$ & $0.36 \pm 0.02^{\mathrm{cd}}$ \\
\hline 23 & SL17-5 & Shanxi (China) & $13.22 \pm 0.28^{c}$ & $8.85 \pm 0.27^{b c}$ & $1.49 \pm 0.03^{\mathrm{cd}}$ & $5.99 \pm 0.13^{c}$ & $0.37 \pm 0.03^{\mathrm{cd}}$ \\
\hline 24 & SYUN10-18 & Shanxi (China) & $13.24 \pm 0.19^{c}$ & $8.88 \pm 0.25^{b c}$ & $1.49 \pm 0.03^{\mathrm{cd}}$ & $6.03 \pm 0.12^{b c}$ & $0.38 \pm 0.01^{\mathrm{cd}}$ \\
\hline 25 & SYUN10-24 & Shanxi (China) & $14.43 \pm 0.30^{\mathrm{c}}$ & $9.40 \pm 0.10^{b c}$ & $1.54 \pm 0.04^{\mathrm{c}}$ & $6.14 \pm 0.05^{b c}$ & $0.43 \pm 0.02^{\mathrm{c}}$ \\
\hline 26 & 20111116 & Tongliao (China) & $12.55 \pm 0.43^{\mathrm{cd}}$ & $8.60 \pm 0.10^{b c}$ & $1.46 \pm 0.04^{\mathrm{cd}}$ & $6.55 \pm 0.09^{b}$ & $0.34 \pm 0.04^{\mathrm{cd}}$ \\
\hline 27 & 20082227 & Tongliao (China) & $12.49 \pm 0.54^{\mathrm{d}}$ & $8.38 \pm 0.44^{\mathrm{c}}$ & $1.49 \pm 0.05^{\mathrm{cd}}$ & $6.21 \pm 0.33^{b c}$ & $0.27 \pm 0.06^{\mathrm{d}}$ \\
\hline 28 & 20102189 & Tongliao (China) & $12.25 \pm 0.52^{\mathrm{d}}$ & $8.83 \pm 0.17^{b c}$ & $1.39 \pm 0.05^{\mathrm{de}}$ & $6.38 \pm 0.34^{b c}$ & $0.32 \pm 0.06^{\mathrm{d}}$ \\
\hline 29 & 20111064 & Tongliao (China) & $13.19 \pm 0.12^{\mathrm{cd}}$ & $9.07 \pm 0.10^{b c}$ & $1.45 \pm 0.02^{\mathrm{cd}}$ & $6.83 \pm 0.26^{b}$ & $0.29 \pm 0.06^{\mathrm{d}}$ \\
\hline 30 & 20111066 & Tongliao (China) & $12.23 \pm 0.65^{\mathrm{d}}$ & $8.68 \pm 0.14^{b c}$ & $1.41 \pm 0.05^{\mathrm{d}}$ & $6.33 \pm 0.22 \mathrm{bc}$ & $0.29 \pm 0.04^{\mathrm{d}}$ \\
\hline 31 & CSR181 & France & $9.72 \pm 0.40 \mathrm{~g}$ & $7.98 \pm 0.15^{\mathrm{cd}}$ & $1.22 \pm 0.02^{\mathrm{f}}$ & $6.17 \pm 0.16^{\mathrm{bc}}$ & $0.28 \pm 0.06^{\mathrm{d}}$ \\
\hline 32 & 20111149 & Tongliao (China) & $12.90 \pm 0.74^{\mathrm{cd}}$ & $8.19 \pm 0.26^{c}$ & $1.58 \pm 0.10^{b c}$ & $6.08 \pm 0.09 \mathrm{bc}$ & $0.27 \pm 0.15^{\mathrm{d}}$ \\
\hline 33 & 20071113 & Tongliao (China) & $10.91 \pm 0.48^{e f}$ & & $1.34 \pm 0.06^{\mathrm{e}}$ & $6.08 \pm 0.19 b c$ & $0.20 \pm 0.04 \mathrm{de}$ \\
\hline 34 & 20091078 & Tongliao (China) & $14.27 \pm 0.21^{\mathrm{c}}$ & $8.71 \pm 0.15^{b c}$ & $1.64 \pm 0.05^{\mathrm{b}}$ & $6.87 \pm 0.14^{b}$ & $0.33 \pm 0.03^{\mathrm{d}}$ \\
\hline 35 & almAB1 & Tongliao (China) & $11.22 \pm 0.13^{\mathrm{e}}$ & $8.51 \pm 0.17^{b c}$ & $1.32 \pm 0.04 \mathrm{e}^{\mathrm{e}}$ & $6.51 \pm 0.27^{b}$ & $0.30 \pm 0.02^{\mathrm{d}}$ \\
\hline 36 & almAB2 & Tongliao (China) & $11.47 \pm 0.05^{\mathrm{e}}$ & $7.87 \pm 0.16^{\mathrm{cd}}$ & $1.46 \pm 0.03^{\mathrm{cd}}$ & $6.75 \pm 0.19^{b}$ & $0.30 \pm 0.03^{\mathrm{d}}$ \\
\hline 37 & $\operatorname{almAB3}$ & Tongliao (China) & $11.86 \pm 0.34$ de & $8.40 \pm 0.53^{c}$ & $1.41 \pm 0.10^{\mathrm{d}}$ & $6.41 \pm 0.30 \mathrm{bc}$ & $0.22 \pm 0.03 \mathrm{de}$ \\
\hline 38 & $\operatorname{almAB} 4$ & Tongliao (China) & $11.24 \pm 0.48^{\mathrm{e}}$ & $8.37 \pm 0.17^{c}$ & $1.34 \pm 0.06^{\mathrm{e}}$ & $6.11 \pm 0.08^{b c}$ & $0.28 \pm 0.06^{\mathrm{d}}$ \\
\hline 39 & Red Caster 1 & Zibo (China) & $12.68 \pm 0.08^{\mathrm{cd}}$ & $8.21 \pm 0.05^{c}$ & $1.54 \pm 0.02^{\mathrm{c}}$ & $6.94 \pm 0.01^{\mathrm{b}}$ & $0.34 \pm 0.01^{\mathrm{cd}}$ \\
\hline 40 & Red Caster 2 & Zibo (China) & $13.97 \pm 0.09^{c}$ & $8.88 \pm 0.12^{b c}$ & $1.57 \pm 0.06^{\mathrm{bc}}$ & $6.41 \pm 0.09 \mathrm{bc}$ & $0.35 \pm 0.03^{\mathrm{cd}}$ \\
\hline 41 & Red Caster 3 & Zibo (China) & $12.83 \pm 0.08^{\mathrm{cd}}$ & $8.41 \pm 0.14^{\mathrm{c}}$ & $1.53 \pm 0.02^{c}$ & $5.85 \pm 0.12^{c}$ & $0.30 \pm 0.01^{\mathrm{d}}$ \\
\hline 42 & Yellow Caster 1 & Zibo (China) & $12.53 \pm 0.07^{\mathrm{cd}}$ & $8.16 \pm 0.25^{c}$ & $1.54 \pm 0.03^{c}$ & $5.82 \pm 0.15^{\mathrm{c}}$ & $0.30 \pm 0.02^{\mathrm{d}}$ \\
\hline 43 & Yellow Caster 2 & Zibo (China) & $13.77 \pm 0.08^{c}$ & $9.04 \pm 0.33^{b c}$ & $1.52 \pm 0.04^{\mathrm{c}}$ & $6.52 \pm 0.08^{b}$ & $0.38 \pm 0.01^{\mathrm{cd}}$ \\
\hline 44 & Hongwuci & Shaanxi (China) & $12.87 \pm 0.04^{\mathrm{cd}}$ & $8.95 \pm 0.34 \mathrm{bc}$ & $1.44 \pm 0.03^{\mathrm{d}}$ & $6.50 \pm 0.22^{b}$ & $0.37 \pm 0.02^{\mathrm{cd}}$ \\
\hline 45 & $\mathrm{~T} 5$ & Zibo (China) & $11.52 \pm 0.05$ de & $7.82 \pm 0.23^{\mathrm{cd}}$ & $1.47 \pm 0.02 \mathrm{~cd}$ & $6.64 \pm 0.24^{b}$ & $0.23 \pm 0.01 \mathrm{de}$ \\
\hline 46 & Vietnam Castor & Vietnam & $15.58 \pm 0.24^{\mathrm{b}}$ & $9.34 \pm 0.31^{b c}$ & $1.69 \pm 0.10^{\mathrm{ab}}$ & $6.55 \pm 0.19^{b}$ & $0.44 \pm 0.03^{c}$ \\
\hline 47 & Gua1 & Pakistan & $13.58 \pm 0.14^{\mathrm{c}}$ & $8.63 \pm 0.14^{b c}$ & $1.57 \pm 0.02^{b c}$ & $6.12 \pm 0.15^{b c}$ & $0.39 \pm 0.02^{\mathrm{cd}}$ \\
\hline 48 & Gua2 & Pakistan & $12.03 \pm 0.09 \mathrm{~d}$ & $7.63 \pm 0.18^{\mathrm{cd}}$ & $1.58 \pm 0.02^{b c}$ & $5.71 \pm 0.14^{\mathrm{c}}$ & $0.28 \pm 0.08^{\mathrm{d}}$ \\
\hline 49 & Paraguay Castor & Paraguay & $15.59 \pm 0.33^{b}$ & $9.54 \pm 0.27^{b}$ & $1.63 \pm 0.03^{b}$ & $6.68 \pm 0.31^{b}$ & $0.48 \pm 0.04^{b c}$ \\
\hline 50 & Malaysia Castor & Malaysia & $11.18 \pm 0.12^{\mathrm{e}}$ & $6.56 \pm 0.09 \mathrm{de}$ & $1.70 \pm 0.10^{\mathrm{a}}$ & $4.80 \pm 0.11^{\mathrm{d}}$ & $0.18 \pm 0.03$ de \\
\hline
\end{tabular}


Table 1. Cont.

\begin{tabular}{|c|c|c|c|c|c|c|c|}
\hline No. & Variety & Location & Length (mm) & Width (mm) & L/W Ratio & $\begin{array}{l}\text { Thickness } \\
\text { (mm) }\end{array}$ & Weight (g) \\
\hline 51 & Ethiopia Castor & Ethiopia & $18.24 \pm 0.21^{\mathrm{a}}$ & $15.11 \pm 0.24^{\mathrm{a}}$ & $1.21 \pm 0.01^{\mathrm{f}}$ & $7.83 \pm 0.22^{a}$ & $1.06 \pm 0.02^{a}$ \\
\hline 52 & Indonesia Castor & Indonesia & $15.80 \pm 0.18^{b}$ & $8.97 \pm 0.18^{b c}$ & $1.76 \pm 0.03^{a}$ & $6.08 \pm 0.18^{b c}$ & $0.43 \pm 0.03^{c}$ \\
\hline 53 & Indonesia Castor & Indonesia & $10.19 \pm 0.09^{f}$ & $6.57 \pm 0.27$ de & $1.55 \pm 0.02 \mathrm{bc}$ & $4.95 \pm 0.09 \mathrm{~d}$ & $0.18 \pm 0.01$ de \\
\hline 54 & Nigeria Castor & Nigeria & $12.55 \pm 0.17^{\mathrm{cd}}$ & $7.91 \pm 0.38^{\mathrm{cd}}$ & $1.59 \pm 0.05^{b c}$ & $5.57 \pm 0.14^{\mathrm{c}}$ & $0.23 \pm 0.02$ de \\
\hline
\end{tabular}

Each value represents the mean \pm standard error $(n=10)$. The different superscript letters a-d indicate the significant difference based on Duncan's Multiple Range Test $(p \leq 0.05)$.

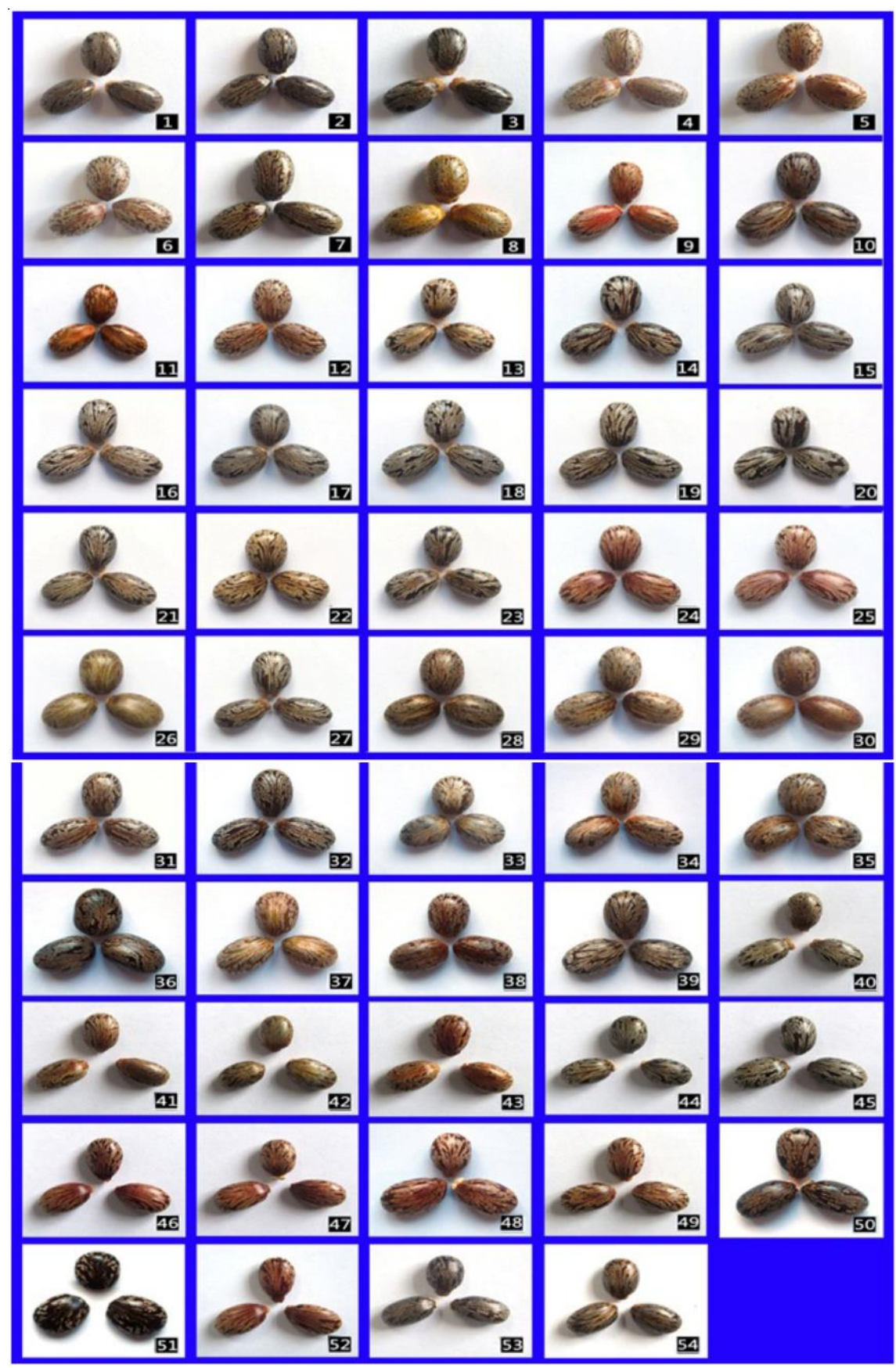

Figure 1. The seed patterns of 54 R. communis L. samples were collected from different locations in the world. See Table 1 for abbreviations of the varieties. 


\subsection{DNA Extraction}

The castor seeds were first peeled and split in half, then were put into plastic bags and kept frozen in the temperature of $-80^{\circ} \mathrm{C}$. DNA was extracted from seed tissue $(\sim 0.1 \mathrm{~g})$ ground in liquid nitrogen by using Plant Genomic DNA kit (EP309, Beijing Zoman Biotechnology Co., Ltd., Beijing, China).

The extracted DNA was examined through electrophoresis on $1.0 \%$ agarose gel and quantified by a spectrophotometer (BioRad, Germany). Then, the DNA samples were diluted into $50 \mathrm{ng} / \mu \mathrm{L}$ and stored at $-20^{\circ} \mathrm{C}$ for PCR amplification.

\subsection{PCR Amplification of ISSR Marker}

A total of 100 ISSR primers (University of British Columbia, Vancouver, BC, Canada) were tested with nine (UBC \#808, \#824, \#827, \#836, \#841, \#842, \#847, \#857, and \#873) showing high reproducibility and accuracy selected for PCR amplification. The PCR reaction was performed as described in literature with a minor modification [36]. The optimal reaction condition of ISSR-PCR amplification contained $2.5 \mu \mathrm{L}$ template DNA, $2 \mu \mathrm{L} 10 \times \mathrm{PCR}$ buffer,

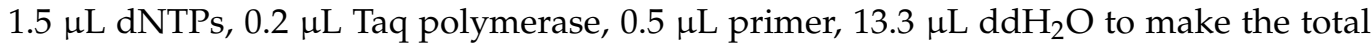
volume of $20 \mu \mathrm{L}$.

The cycling conditions were as follows: $4 \mathrm{~min}$ at $94{ }^{\circ} \mathrm{C}$ for an initiation step, followed by 40 cycles of $30 \mathrm{~s}$ at $94{ }^{\circ} \mathrm{C}, 30 \mathrm{~s}$ at a primer-appropriate temperature, and $2 \mathrm{~min}$ at $72{ }^{\circ} \mathrm{C}$, and finalized at a final cycle of $10 \mathrm{~min}$ at $72{ }^{\circ} \mathrm{C}$. PCR products were detected by electrophoresis on a $2.0 \%$ agarose gel stained with $0.1 \mu \mathrm{L} / \mathrm{mL}$ of DNAgreen (UV) (Tiandz, China) and run in $1 \times$ TAE buffer at $100 \mathrm{~V}$ for $40 \mathrm{~min}$. PCR products were photographed by the Bio-image System (BioRad, Germany). Each PCR reaction was repeated three times.

\subsection{PCR Amplification of RAPD Marker}

The RAPD analysis was performed using nine primers as previously described by Powell et al. [37]. The composition of the PCR reaction mixture contained $2.2 \mu \mathrm{L}$ of DNA template, $2 \mu \mathrm{L} 10 \times$ PCR Buffer, $1.5 \mu \mathrm{L}$ dNTPs, $0.2 \mu \mathrm{L}$ Taq polymerase, $0.5 \mu \mathrm{L}$ Primer, and $13.6 \mu \mathrm{L}$ ddH2O. The cycling conditions were as follows: 4 min at $94{ }^{\circ} \mathrm{C}$ for an initiation step, followed by 40 cycles of $30 \mathrm{~s}$ at $94{ }^{\circ} \mathrm{C}, 30 \mathrm{~s}$ at a primer-appropriate temperature, and $2 \mathrm{~min}$ at $72{ }^{\circ} \mathrm{C}$, and a final cycle of $10 \mathrm{~min}$ at $72{ }^{\circ} \mathrm{C}$. Amplified products were separated on $2 \%$ agarose gel in $1 \times$ TAE buffer by electrophoresis at $100 \mathrm{~V}$ for $40 \mathrm{~min}$ and photographed by Bio-image System (BioRad, CA, USA).

\subsection{Data Analysis}

SPSS 19.0 was used for one-way analysis of variance (ANOVA) and differences between means were assessed by Duncan's multiple range test $(p \leq 0.05)$. Each band amplified with ISSR and RAPD primers was manually scored as present (1) or absence (0). Only clear and reproducible bands were counted (Table S1). The genetic relationship between 54 castor varieties were evaluated by UPGMA analyses [25]. The genetic similarity of the castor varieties based on Jaccard's index [38]. The principle coordinate analysis (PcoA) was performed by NTSYS-pc version 2.10 software for three-dimensional distribution analysis [39].

\section{Results}

Generally, morphological characters (such as seed size and seed coat color) are an important factor in classification of castor varieties and evaluation of genetic diversity. In Table 1, the 51-Eth variety was superior to other varieties in seed length, width, thickness, and weight. The seed coat color pattern of the 54 varieties is given in Figure 1. Cluster analysis was carried out based on the morphological characteristics of seed size and color. Results showed that the 54 castor samples could be divided into three main groups (i.e., Clusters I, II, and III) with the genetic similarity coefficient ranging from 0.02 to 3.78 with an average of 1.90 (Figure 2). There were a total of 6, 32, and 15 varieties grouped in Clusers 1,2, and 3, respectively, with variety 51-Eth in its own group. The genetic similarity 
coefficient of the 51-Eth variety was evidently different from those of Clusters I, II, and III. Most of the seed color was brown or dark brown, and some varieties were red-brown (9-Jor, 11-Yun, 24-Sha, 25-Sha, 30-Ton, 34-Ton, 35-Ton, 41-Zi, 43-Zi, 46-Vie, 47-Pak, 48-Pak, 49-Par, and 52-Indo), while three varieties (4-Ind, 6-Ind, and 37) were light brown, and two varieties (8-Fra and 26-Ton) were yellow-brown.

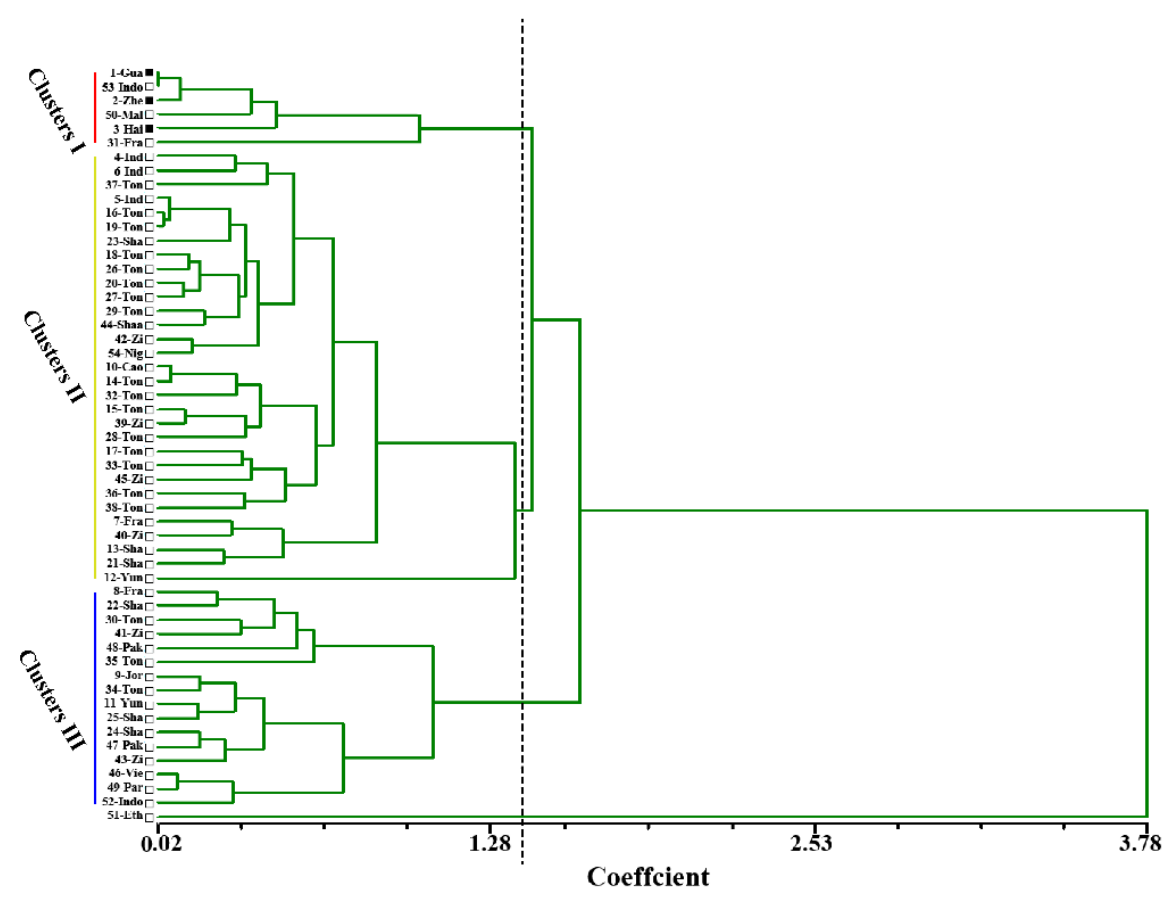

Figure 2. Classification of 54 castor samples based on six morphological traits.

\subsection{ISSR Analysis}

A total of 9 out of 100 primers that produced clear and reproducible bands were selected in the present study. Those primers produced 83 bands in total and the lengths of the amplified fragments ranged from $200 \mathrm{bp}$ to $2700 \mathrm{bp}$ (Table 2).

Table 2. Amplification of ISSR markers in 54 samples of castor seeds.

\begin{tabular}{ccccccc}
\hline $\begin{array}{c}\text { Primer } \\
\text { Code }\end{array}$ & $\begin{array}{c}\text { Sequence } \\
\left(\mathbf{5}^{\prime}-\mathbf{3}^{\prime}\right)\end{array}$ & $\begin{array}{c}\text { Tm } \\
\left({ }^{\circ} \mathbf{C}\right)\end{array}$ & TNB & NPB & PPB (\%) & $\begin{array}{c}\text { Range of the Band } \\
\text { Size (bp) }\end{array}$ \\
\hline UBC-808 & $(\mathrm{AG})_{8}-\mathrm{C}$ & 52 & 9 & 9 & 100.00 & $600 \sim 2500$ \\
UBC-827 & $(\mathrm{AC})_{8}-\mathrm{G}$ & 52 & 9 & 5 & 55.55 & $450 \sim 2400$ \\
UBC-836 & $(\mathrm{AG})_{8}-\mathrm{YA}$ & 50 & 11 & 6 & 54.55 & $250 \sim 2400$ \\
UBC-841 & $(\mathrm{GA})_{8}-\mathrm{YC}$ & 52 & 7 & 6 & 85.71 & $300 \sim 1800$ \\
UBC-842 & $(\mathrm{GA})_{8}-\mathrm{YG}$ & 52 & 12 & 9 & 75.00 & $200 \sim 2700$ \\
UBC-847 & $(\mathrm{CA})_{8}-\mathrm{RC}$ & 52 & 5 & 4 & 80.00 & $2300 \sim 500$ \\
UBC-856 & $(\mathrm{AC})_{8}-\mathrm{YA}$ & 50 & 10 & 7 & 70.00 & $400 \sim 2200$ \\
UBC-857 & $(\mathrm{AC})_{8}-\mathrm{YG}$ & 52 & 10 & 9 & 90.00 & $550 \sim 2600$ \\
UBC-873 & $(\mathrm{GACA})_{4}$ & 50 & 10 & 6 & 60.00 & $450 \sim 2550$ \\
Mean & & & 9.2 & 6.8 & 74.53 & \\
\hline
\end{tabular}

Note: TNB, total number of bands; NPB, number of polymorphic bands; PPB (\%), percentage of polymorphic bands; $R$ represents either $A$ or $G$ and $Y$ represents either $C$ or T.

The percentage of polymorphic bands per primer ranged from $54.55 \%$ (UBC-836) to $100 \%$ (UBC-808) with an average of $74.53 \%$. As a representative, the ISSR profile of 54 castor samples using UBC-842 primer was shown in Figure 3. 

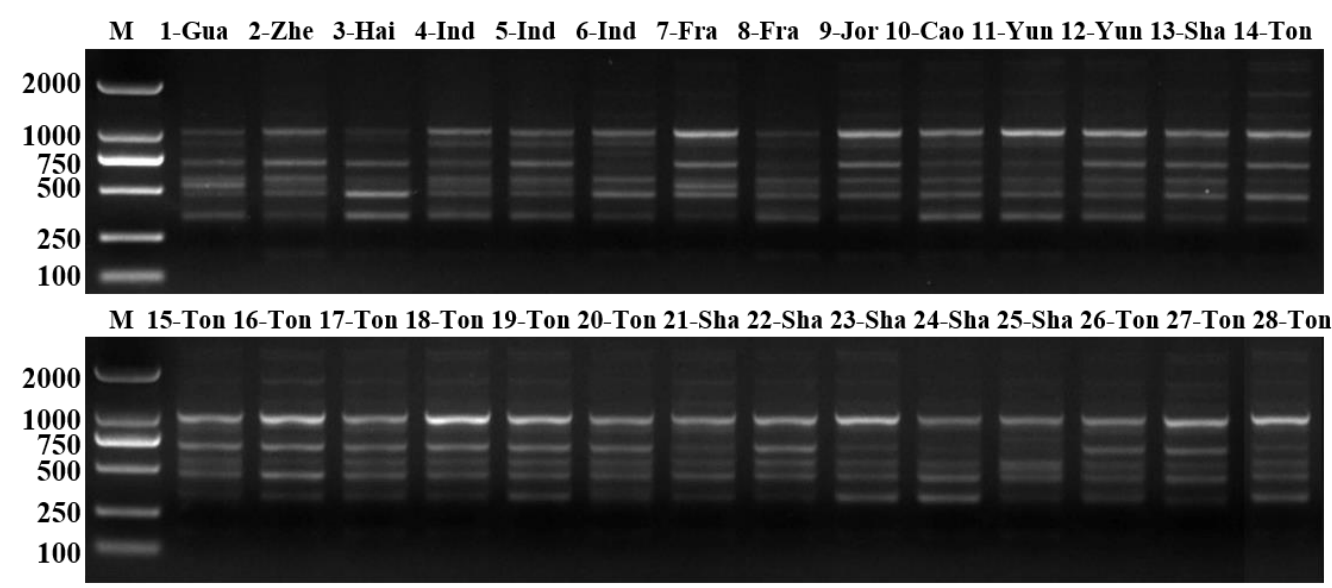

M 29-Ton 30-Ton 31-Fra 32-Ton 33-Ton 34-Ton 35-Ton 36-Ton 37-Ton 38-Ton 39-Zi $40-Z i \quad 41-Z i \quad 42-Z i$

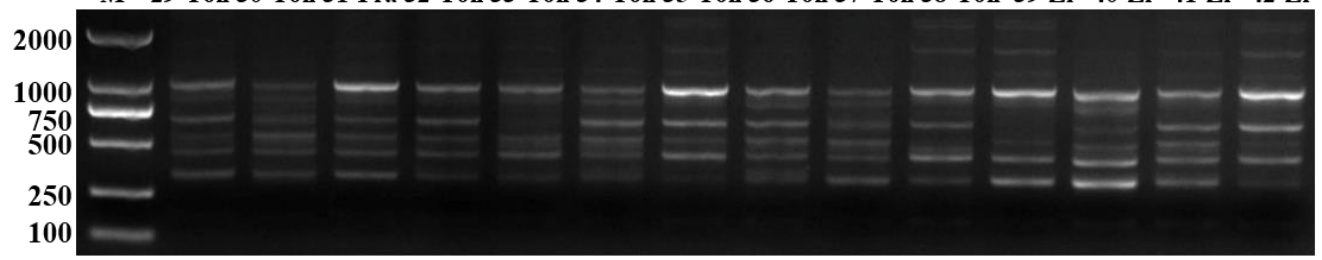

M 43-Zi 44-Shaa 45-Zi 46-Vie 47-Pak 48-Pak 49-Par 50-Mal 51-Eth 52-Indo 53-Indo 54-Nig

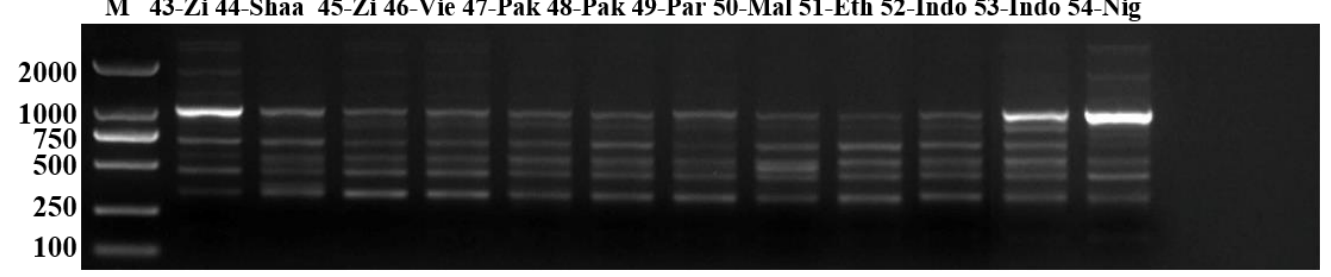

Figure 3. ISSR profiles of 54 R. communis L. samples amplified using primer UBC 842.

The UPGMA dendrogram using ISSR data based on the genetic similarity coefficient showed two main clusters with the genetic similarity coefficient ranging from 0.74 to 0.96 with an average of 0.86 (Figure 4 ).

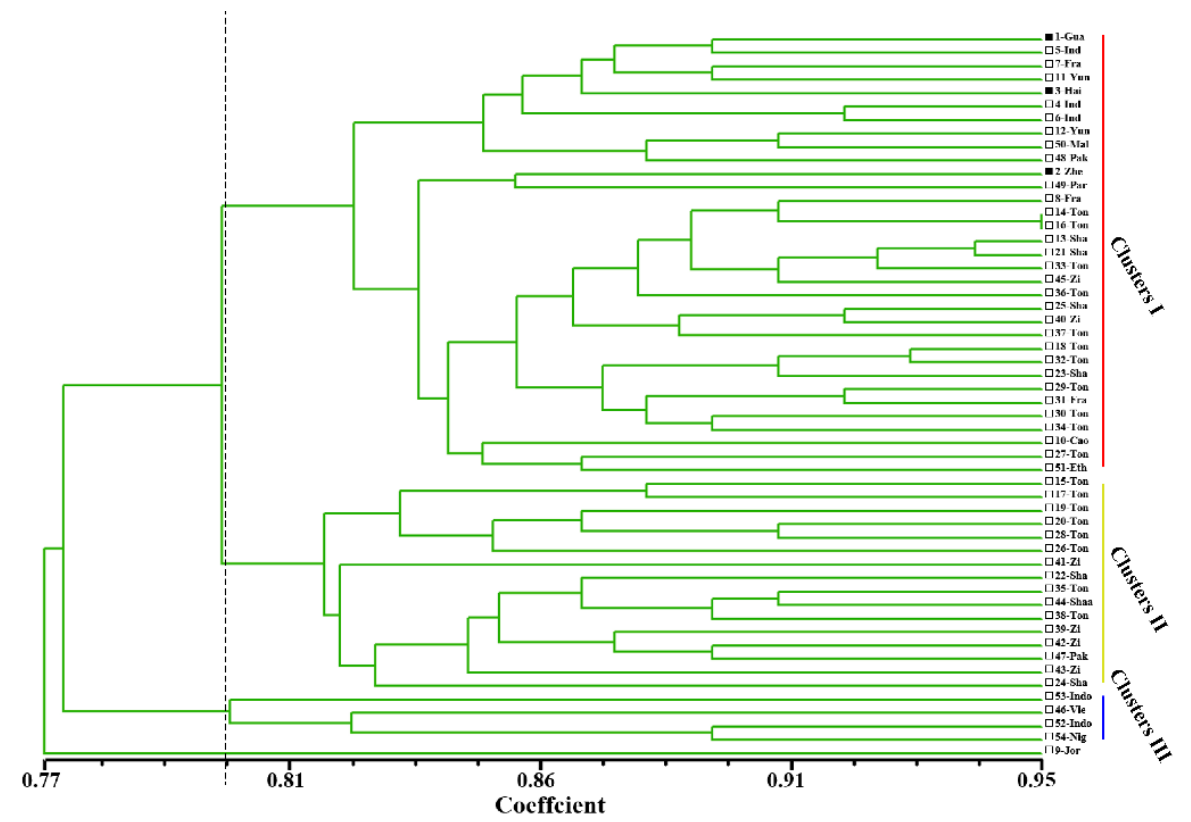

Figure 4. Dendrogram of 54 R. communis L. seed samples based on the UPGMA cluster analysis of ISSR data. 
Two varieties (14-Ton and 16-Ton) showed the highest similarity coefficient (0.97). Clusters I and II included most of the 54 varieties, and Clusters III includes 46-Vie, 52-Indo, 53-Indo and 54-Nig varieties. However, variety 9-Jor was obviously different from those of Cluster I and II, III.

The results of the three-dimensional plot based on the PCoA analysis (Figure 5) were largely consistent with those revealed on the UPGMA clustering (Figure 4).

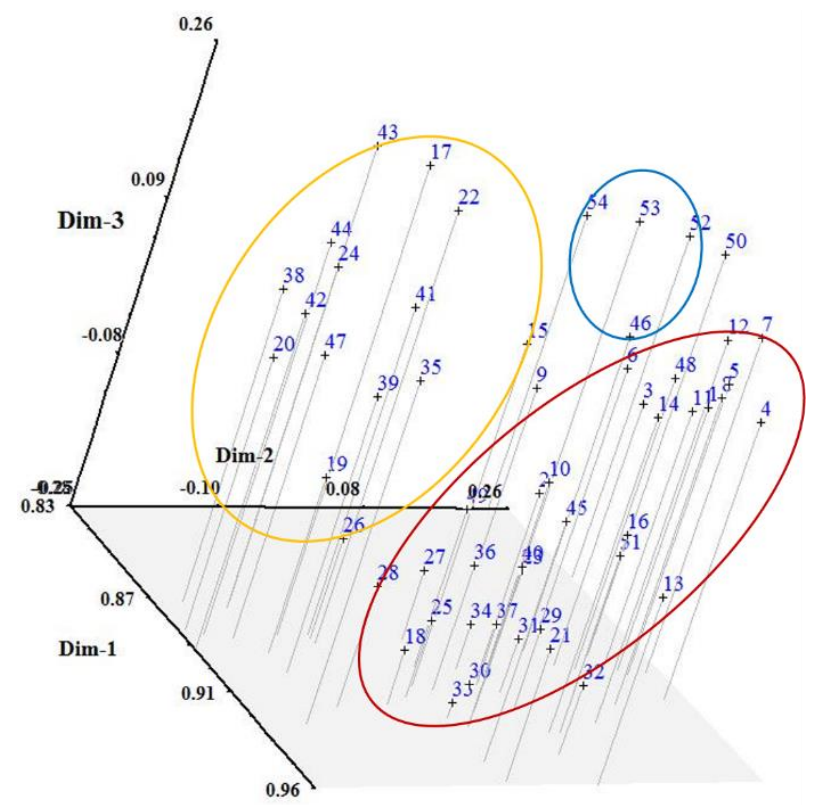

Figure 5. Three-dimensional plot of 54 R. communis L. seed samples (Table 1 ) based on the principal coordinate analysis using Jaccard similarity coefficient of the ISSR markers.

\subsection{RAPD Analysis}

Genetic diversity analysis was performed on 11 out of 20 RAPD primers that were reproducible and provided a unique polymorphism products. These 11 primers produced a total of 90 bands with the lengths of the amplified fragments ranging from $250 \mathrm{bp}$ to 3000 bp (Table 3).

Table 3. Amplification of 11 RAPD markers in 54 castor seed samples.

\begin{tabular}{ccccccc}
\hline $\begin{array}{c}\text { Primer } \\
\text { Code }\end{array}$ & $\begin{array}{c}\text { Sequence } \\
\left(\mathbf{5}^{\prime}-\mathbf{3}^{\prime}\right)\end{array}$ & $\begin{array}{c}\text { Tm } \\
\left({ }^{\circ} \mathbf{C}\right)\end{array}$ & TNB & NPB & PPB (\%) & $\begin{array}{c}\text { Range of the } \\
\text { Bang Size (bp) }\end{array}$ \\
\hline B2 & ACAGGGCTCT & 52 & 6 & 2 & 33.33 & $500 \sim 2500$ \\
B7 & ATCCTGCCTG & 52 & 4 & 1 & 25 & $650 \sim 1400$ \\
B9 & ATCGGGTCGA & 50 & 10 & 8 & 80 & $250 \sim 3000$ \\
B17 & CCGGCCTTAG & 52 & 9 & 7 & 77.78 & $500 \sim 2450$ \\
B19 & CCGGCCTTCC & 52 & 11 & 6 & 54.55 & $250 \sim 2350$ \\
B21 & CCGGGGAAAC & 52 & 11 & 10 & 90.91 & $250 \sim 2350$ \\
B23 & CCGGGGTTTG & 50 & 12 & 8 & 75 & $350 \sim 2700$ \\
F3 & CCTGGGCTGG & 52 & 7 & 4 & 5714 & $450 \sim 2400$ \\
F4 & CCTGGGCTAT & 50 & 6 & 5 & 83.33 & $750 \sim 2700$ \\
OPA-02 & TGCCGAGCTG & 50 & 8 & 2 & 25 & $450 \sim 1950$ \\
OPA-10 & GTGATCGCAG & 50 & 6 & 2 & 33.33 & $500 \sim 2400$ \\
Mean & & & 8.2 & 5 & 60.98 & \\
\hline
\end{tabular}

Note: TNB, total number of bands; NPB, number of polymorphic bands; PPB (\%), percentage of polymorphic bands.

The percentage of polymorphic bands per primer ranged from $25 \%$ (B7 and OPA-02) to $90.91 \%$ (B21) with an average of $60.98 \%$. As a representative, the RAPD profile of 54 castor varieties using B21 primer was shown in Figure 6. 


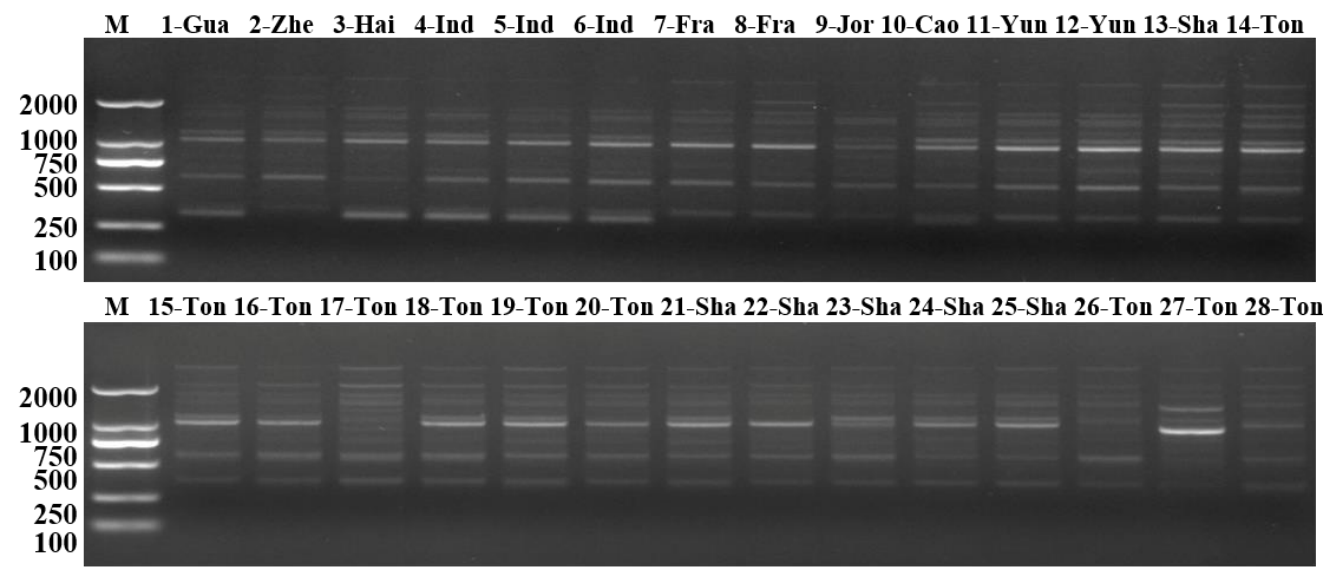

M 29-Ton 30-Ton 31-Fra 32-Ton 33-Ton 34-Ton 35-Ton 36-Ton 37-Ton 38-Ton 39-Zi $40-\mathrm{Zi} \quad 41-\mathrm{Zi} \quad 42-\mathrm{Zi}$

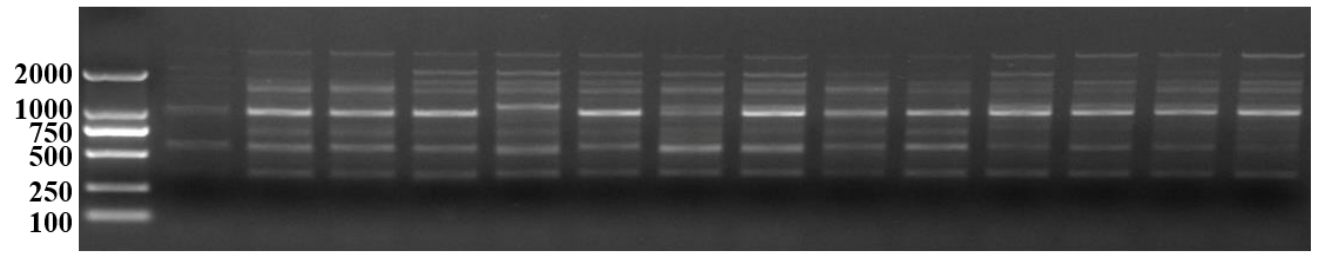

M 43-Zi 44-Sha 45-Zi 46-Vie 47-Pak 48-Pak 49-Par 50-Mal 51-Eth 52-Indo 53-Indo 54-Nig

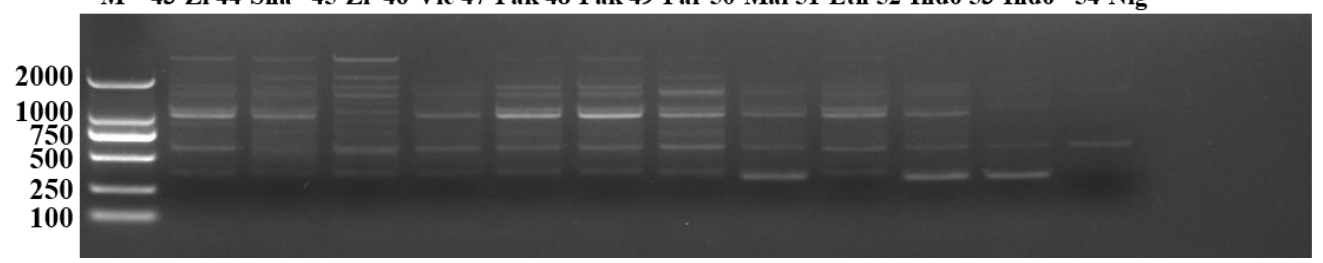

Figure 6. RAPD profiles of 54 R. communis L. seed samples amplified using primer B21.

See Table 1 for the abbreviations of these 54 accessions.

A dendrogram based on UPGMA analysis using RAPD data was shown in Figure 7. The genetic similarity coefficient ranged from 0.75 to 0.99 with an average of 0.85 .

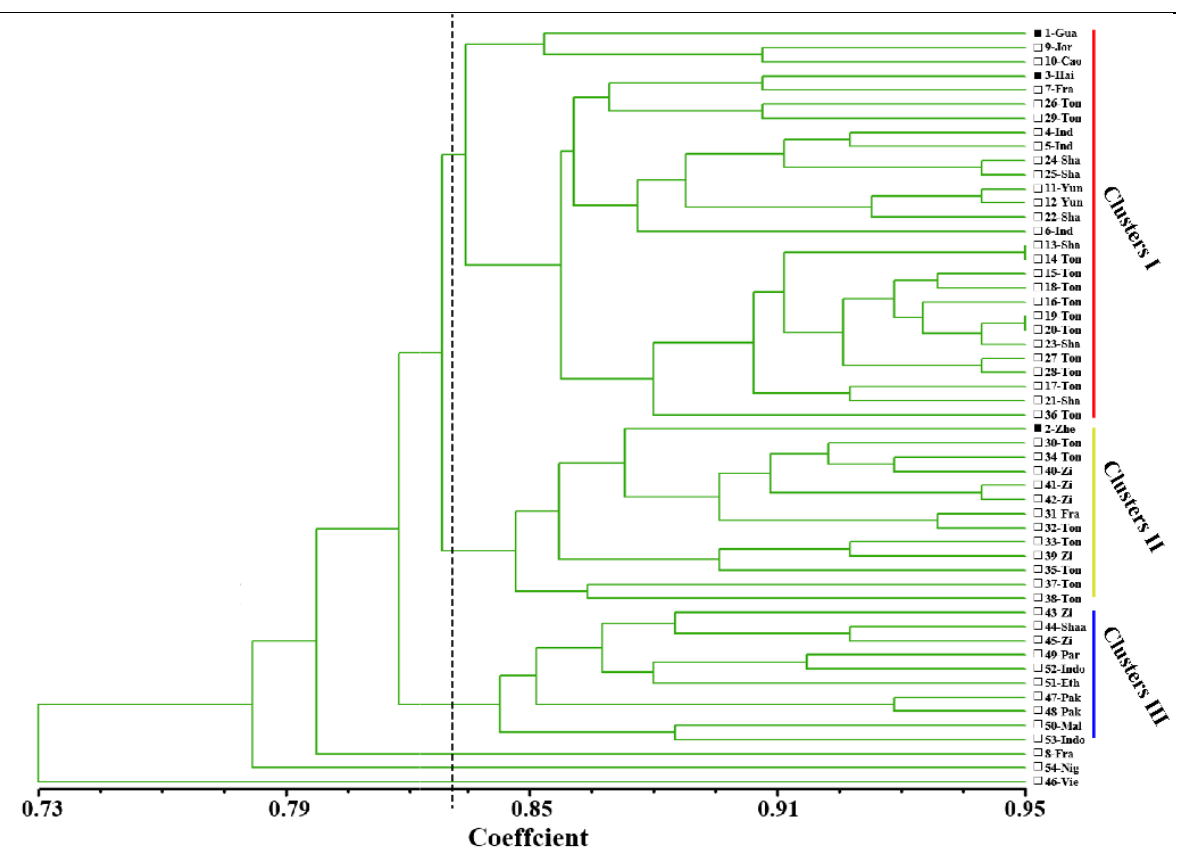

Figure 7. Dendrogram of 54 R. communis L. seed samples generated by the UPGMA cluster analysis based on RAPD markers. 
The 13-Sha and 14-Ton as well as 19-Ton and 20-Ton showed the highest similarity coefficient (0.95), while the lowest similarity coefficient (0.75) was revealed between 4-Ind and 46-Vie. UPGMA cluster analysis based on RAPD data grouped 54 samples into three major Clusters. Like the ISSR analysis, Cluster 1 contained most varieties, while Cluster II comprised 2-Zhe, 30-Ton, 34-Ton, 40-Zi, 41-Zi, 42-Zi, 31-Fra, 32-Ton, 33-Ton, 39-Zi, 35-Ton, 37-Ton and 38-Ton. Cluster III contained ten varieties (i.e., 43-Zi, 44-Sha, 45-Zi, 49-Par, 52-Indo, 51-Eth, 47-Pak, 48-Pak, 50-Mal and 53-Indo). The results of PCoA were comparable to those of cluster analysis with insignificant deviations (Figure 8).

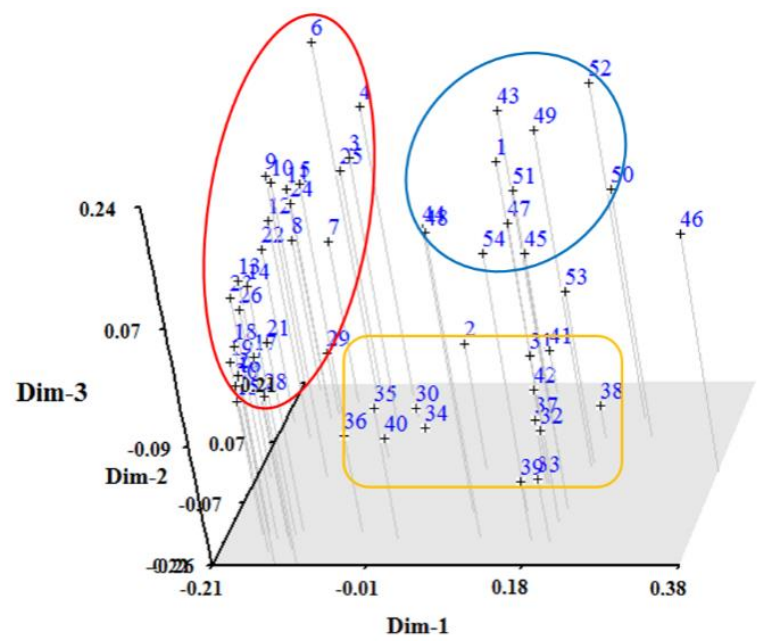

Figure 8. Three-dimensional plot of the PCoA analysis based on RAPD markers of 54 R. communis L. seed samples.

\section{Discussion}

Castor bean seeds were used by people dating from about $4000 \mathrm{BC}$ and were thought to have originated in Eastern Africa, particularly Ethiopia [40]. The application of castor in India, Saudi Arabia, Greece, and Rome has been documented as having anti-inflammatory, antiasthmatic, and cathartic effects [41]. Castor seeds have also been used in China for centuries as a traditional medicine [42]. It is reasonable to assume that castor might have been introduced to China many centuries ago. However, genetic diversity of varieties cultivated in China has not been systematically studied.

In this study, the analysis of genetic diversity of 54 castor samples collected in India, Jordan, France, Vietnam, Pakistan, Paraguay, Malaysia, Ethiopia, Indonesia, Nigeria, and China was carried out based on morphological characters of the castor seed and two molecular markers (RAPD and ISSRs). For a long time, genetic diversity analysis has been done based on the morphological characteristics. Morphological traits display a continuous phenotypic range, and as quantitative traits, they are dominantly controlled by multi genes [43]. Qualitative traits are reported as equally effective in diversity assessment compared with molecular markers in plants [44]. In particular, the size and weight of seeds contribute to the oil content of seeds and are important morphological indicators. The length-to-width ratio of the castor seeds in different varieties ranged from 1.76 (52-Ind) to 1.21 (51-Eth) with an average of 1.51 . This ratio was not significantly different from the ratio reported in previous studies [45]. The 54 castor seeds were divided into five groups (brown, light brown, dark brown, red-brown, and yellow-brown) based on stripe color and background color. The stripe pattern of seed is an important factor in characterizing genetic diversity, but it was difficult to investigate this trait due to its great variability. The 54 castor varieties were clustered into three groups according to six morphological characteristics. This result was different from that of the clustering analysis based on molecular markers. Similar results have been reported in previous studies, indicating that genetic diversity analysis based on combined RAPD and ISSR markers may be a more useful tool for the identification of Brahmi than morphological characters [46]. Morphological and 
geographical patterns may also reflect genetic characteristics due to the environmental influences during the stages of plant development and reproduction. In contrast, both RAPD and ISSR technology are useful tools for the classification and genetic analysis of plant varieties compared to morphological analysis $[47,48]$. Both RAPD and ISSR markers show high polymorphism and are simple and cheap to generate. Therefore, they are widely used for the preservation studies of varieties and phylogenetic analysis $[49,50]$.

Results of the genetic diversity of 54 castor varieties demonstrated that the ISSR and RAPD markers showed high polymorphism with an average of $74.59 \%$ and $60.98 \%$, respectively. These values are comparable with $68.08 \%$ and $80.2 \%$ but much higher than $38 \%$ and $54 \%$ as previously reported by Gajera et al. [51] and Kallamadi et al. [5], respectively. Our results show that the genetic diversity among the 54 varieties of castor collected in different regions in the world is quite large. These results are similar to those reported in the previous studies showing the ample diversity among the castor genotypes [52]. Some different topological arrangements of these 54 varieties were revealed in the UPGMA dendrograms based on ISSR and RAPD markers. For example, the variety 9-Jor was revealed in its own group in the ISSR dendrogram but grouped into cluster I in the RAPD dendrogram. Furthermore, the variety 54-Nig was grouped in Clusters III and II in ISSR and RAPD dendrograms, respectively. These differences shown in UPGMA dendrograms are probably due to the polymorphism in the different regions of the castor genome. By using two molecular markers, the genetic background of 54 castor samples can be identified. The numbers of bands amplified by primers of ISSR and RAPD markers are different, ranging from the minimum of 4 or 5 to the maximum of 10 to 12. The different DNA amplification bands revealed in different varieties reflect the differences in genetic background.

Worldwide, Parzies et al. (2008) have categorized varieties of castor into two groups with Group a containing varieties collected from Asian countries (i.e., India, China, Pakistan, Indonesia, Jordan, and Paraguay), while Group b contains varieties collected from Americas (i.e., USA, Brazil, Cuba, and Argentina) [24]. In our study, out of 54 genotypes, 17 varieties were collected from areas outside China and 37 were distributed in China. Cluster I contains a large number of cultivars collected from China closely related to three wild accessions (1-Gua, 2-Zhe, and 3-Hai), indicating that these wild germplasms could be the putative progenitors of the cultivars of Cluster I (Figures 4 and 7). Furthermore, varieties collected from Vietnam, Indonesia, and Nigeria were identified in Cluster III (Figure 4), together with varieties collected from Vietnam, Malaysia, Pakistan, Paraguay, Ethiopia, and Indonesia (Figure 7), indicating that these varieties share similar genetic backgrounds. The studies of Kallamadi et al. [5], based on the combined data of the three-marker system, showed similar results with these accessions classified into three major clusters, while the Indian and Nigerian accessions were clustered in two large groups, respectively. These results indicated that gene flow occurred frequently worldwide, which may be attributed to castor being either self-pollinated or cross-pollinated by wind, instead of using outcrossing as a predominant mode of reproduction [53]. However, the alternative hypothesis states that castor oil was not dispersed widely after its initial introduction. Therefore, the dispersal pattern appears to be dependent on human introduction or physical transport, owing to the heavy seeds [54].

The results of PCoA used to determine the spatial representation of genetic distances among the castor varieties were consistent with the results of genetic differentiation based on cluster analysis. The results of PCoA based on ISSR and RAPD markers differed slightly from those of the UPGMA dendrogram. The results of genetic diversity analyses based on both morphological and molecular data showed that three varieties (9-Jor, 46-Vie, and 51-Eth) showed larger genetic differences compared to other varieties. Therefore, the larger genetic distance of these three varieties may provide rich genetic resources to satisfy breeding requirements. Indeed, our results showed that we can effectively discriminate the genetic difference and phylogenetic relationship among castor varieties based on ISSR and RAPD markers. Furthermore, these results help establish the theoretical foundation for selection, genetic preservation, and breeding of the castor varieties. Our results demonstrate 
the utility of wild germplasm to exploit the unique caster breeding resources. Moreover, the castor resources in China showed a narrow genetic base. Therefore, we recommend that more castor resources be introduced to China to enrich the local breeding materials.

\section{Conclusions}

In the present study, we combined ISSR and RAPD markers to assess the genetic relationship of $54 R$. communis samples collected worldwide (wild or cultivated varieties). Cluster analysis based on morphological data (seed length, width, thickness, weight, length to width ratio, and seed color) grouped all 54 castor samples into three main clusters. The results of PCoA and UPGMA cluster analysis were consistent with each other. The present study showed genetic divergence between the China elite local lines and foreign sources but the overall genetic variation was not extremely large despite the geographical distance. These results are important references for further resource exploitation and conservation of the genetic resources of castor.

Supplementary Materials: The following are available online at https:/ /www.mdpi.com/2073-439 5/11/3/457/s1, Figure S1: Global distribution of the 54 R. communis L. seed accessions used in this study. The sample numbers are listed in Table 1, Table S1: Scoring of amplified bands of 54 samples of castor seeds based on ISSR and RAPD markers.

Author Contributions: H.K., P.L., S.L. and A.W. conducted the experiments. H.K., Y.Z. and F.H. wrote the manuscript. Z.Y., G.Z., Z.H. and D.T. edited the manuscript. H.W. and F.M. critically revised the draft and updated the manuscript for publication. All authors have read and agreed to the published version of the manuscript.

Funding: This research was funded by [the Fundamental Research Funds for the Central Universities] grant number [2572018CG05], [Natural Science Foundation of Inner Mongolia Autonomous Region] grant number [2017MS0339], [Inner Mongolia Autonomous Region "grassland talents" project] grant number [201511], [Inner Mongolia Autonomous Region grassland talents innovation team supported project of castor molecular breeding innovation research team (2017), and Subproject of science and technology reserving project of Inner Mongolia University for Nationalities] grant number [2018NDCB05-2].

Institutional Review Board Statement: Not applicable.

Informed Consent Statement: Informed consent was obtained from all subjects involved in the study.

Data Availability Statement: Data is contained within the article or supplementary material.

Acknowledgments: This project was supported by the Fundamental Research Funds for the Central Universities (2572018CG05), Natural Science Foundation of Inner Mongolia Autonomous Region (2017MS0339), Inner Mongolia Autonomous Region “grassland talents" project (201511), Inner Mongolia Autonomous Region grassland talents innovation team supported project of castor molecular breeding innovation research team (2017), and Subproject of science and technology reserving project of Inner Mongolia University for Nationalities (2018NDCB05-2).

Conflicts of Interest: The authors declare no conflict of interest.

\section{References}

1. Muraguri, S.; Xu, W.; Chapman, M.; Muchugi, A.; Oluwaniyi, A.; Oyebanji, O.; Liu, A.Z. Intraspecific variation within Castor bean (Ricinus communis L.) based on chloroplast genomes. Ind. Crop. Prod. 2020, 155, 112779. [CrossRef]

2. Santos, C.M.D.; Endres, L.; Ferreira, V.M.; Silva, J.V.; Rolim, E.V.; Wanderley, H.C.L.F. Photosynthetic capacity and water use efficiency in Ricinus communis (L.) under drought stress in semi-humid and semi-arid areas. Acad. Bras. Cienc. 2017, 89, 3015-3029. [CrossRef]

3. Sausen, T.L.; Luis Mauro, G.R. Growth and carbon assimilation limitations in Ricinus communis (Euphorbiaceae) under soil water stress conditions. Acta Bot. Bras. 2010, 24, 648-654. [CrossRef]

4. Thatikunta, R.; Siva Sankar, A.; Sreelakshmi, J.; Palle, G.; Leela, C.; Durga Rani, C.V.; Gouri Shankar, V.; Lavanya, B.; Narayana Reddy, P.; Dudhe, M.Y. Utilization of in silico EST-SSR markers for diversity studies in castor (Ricinus communis L.). Physiol. Mol. Biol. Plants 2016, 22, 535-545. [CrossRef] [PubMed] 
5. Kallamadi, P.R.; Nadigatla, V.P.R.G.R.; Mulpuri, S. Molecular diversity in castor (Ricinus communis L.). Ind. Crop. Prod. 2015, 66, 271-281. [CrossRef]

6. Lei, P.; Liu, Z.; Hu, Y.; Kim, H.; Liu, S.; Liu, J.; Xu, L.; Li, J.; Zhao, Y.; Yu, Z.; et al. Transcriptome analysis of salt stress responsiveness in the seedlings of wild and cultivated Ricinus communis L. J. Biotechnol. 2021, 327, 106-116. [CrossRef] [PubMed]

7. Jeong, G.T.; Park, D.H. Optimization of biodiesel production from castor oil using response surface methodology. Appl. Biochem. Biotechnol. 2009, 156, 1-11. [CrossRef]

8. Severino, L.S.; Auld, D.L.; Baldanzi, M.; Cândido, M.J.D.; Chen, G.; Crosby, W.; Tan, D.; He, X.; Lakshmamma, P.; Lavanya, C.; et al. A Review on the Challenges for Increased Production of Castor. Agron. J. 2012, 104, 853. [CrossRef]

9. Roetheli, J.C.; Roetheli, L.K.; Roetheli, B.D. Castor: Assessing the Feasibility of US Production: Summary of Workshop Held at Plainview; Texas: Growing Industrial Material Series; FAO: Rome, Italy, 1991.

10. Yang, T.; Lu, J.; Yeboah, A.; Gu, S.; Li, D.; Shi, Y.; Yin, X. Construction of castor functional markers fingerprint and analysis of genetic diversity. Biocell 2020, 44, 381-388. [CrossRef]

11. Wang, M.L.; Dzievit, M.; Chen, Z.; Morris, J.B.; Norris, J.E.; Barkley, N.A.; Tonnis, B.; Pederson, G.A.; Yu, J. Genetic diversity and population structure of castor (Ricinus communis L.) germplasm within the US collection assessed with EST-SSR markers. Genome 2017, 60, 193-200. [CrossRef]

12. Agyenim-Boateng, K.G.; Lu, J.; Shi, Y.; Zhang, D.; Yin, X. SRAP analysis of the genetic diversity of wild castor (Ricinus communis L.) in South China. PLoS ONE 2019, 14, e219667. [CrossRef] [PubMed]

13. Ahn, Y.-J.; Vang, L.; McKeon, T.A.; Chen, G.Q. High-frequency plant regeneration through adventitious shoot formation in castor (Ricinus commuinis L.). In Vitro Cell. Dev. Biol.-Plant 2007, 43, 9-15. [CrossRef]

14. Yu, A.; Li, F.; Liu, A. Comparative proteomic and transcriptomic analyses provide new insight into the formation of seed size in castor bean. BMC Plant Biol. 2020, 20, 48. [CrossRef] [PubMed]

15. Sanchez-Alvarez, A.; Ruiz-Lopez, N.; Javier Moreno-Perez, A.; Martinez-Force, E.; Garces, R.; Salas, J.J. Agrobacterium-Mediated Transient Gene Expression in Developing Ricinus communis Seeds: A First Step in Making the Castor Oil Plant a Chemical Biofactory. Front. Plant Sci. 2019, 10, 1410. [CrossRef]

16. Fan, W.; Lu, J.; Pan, C.; Tan, M.; Lin, Q.; Liu, W.; Li, D.; Wang, L.; Hu, L.; Wang, L.; et al. Sequencing of Chinese castor lines reveals genetic signatures of selection and yield-associated loci. Nat. Commun. 2019, 10, 3418. [CrossRef] [PubMed]

17. Menssen, M.; Linde, M.; Omondi, E.O.; Abukutsa-Onyango, M.; Dinssa, F.F.; Winkelmann, T. Genetic and morphological diversity of cowpea (Vigna unguiculata (L.) Walp.) entries from East Africa. Sci. Hortic.-Amst. 2017, 226, 268-276. [CrossRef]

18. Bird, C.; Schweizer, M.; Roberts, A.; Austin, W.E.N.; Knudsen, K.L.; Evans, K.M.; Filipsson, H.L.; Sayer, M.D.J.; Geslin, E.; Darling, K.F. The genetic diversity, morphology, biogeography, and taxonomic designations of Ammonia (Foraminifera) in the Northeast Atlantic. Mar. Micropaleontol. 2020, 155, 101726. [CrossRef]

19. Worku, N.; Heslop-Harrison, J.S.; Adugna, W. Diversity in 198 Ethiopian linseed (Linum usitatissimum) accessions based on morphological characterization and seed oil characteristics. Genet. Resour. Crop Evol. 2015, 62, 1037-1053. [CrossRef]

20. Godwin, I.D.; Aitken, E.A.B.; Smith, L.W. Application of intersimple sequence repeat (ISSR) markers to plant genetics. Electrophoresis 1997, 18, 1524-1528. [CrossRef]

21. Linos, A.; Nikoloudakis, N.; Katsiotis, A.; Hagidimitriou, M. Genetic structure of the Greek olive germplasm revealed by RAPD, ISSR and SSR markers. Sci. Hortic.-Amst. 2014, 175, 33-43. [CrossRef]

22. Pecina-Quintero, V.; Anaya-López, J.L.; Núñez-Colín, C.A.; Zamarripa-Colmenero, A.; Montes-García, N.; Solís-Bonilla, J.L.; Aguilar-Rangel, M.R. Assessing the genetic diversity of castor bean from Chiapas, México using SSR and AFLP markers. Ind. Crop. Prod. 2013, 41, 134-143. [CrossRef]

23. Reddy, M.P.; Sarla, N.; Siddiq, E.A. Inter simple sequence repeat (ISSR) polymorphism and its application in plant breeding. Euphytica 2002, 128, 9-17. [CrossRef]

24. Allan, G.; Williams, A.; Rabinowicz, P.D.; Chan, A.P.; Ravel, J.; Keim, P. Worldwide genotyping of castor bean germplasm (Ricinus communis L.) using AFLPs and SSRs. Genet. Resour. Crop Evol. 2007, 55, 365-378. [CrossRef]

25. Liu, S.; Yin, X.G.; Lu, J.N.; Liu, C.; Bi, C.; Zhu, H.B.; Shi, Y.Z.; Zhang, D.; Wen, D.Y.; Zheng, J.; et al. The first genetic linkage map of Ricinus communis L. based on genome-SSR markers. Ind. Crop. Prod. 2016, 89, 103-108. [CrossRef]

26. Vijayan, K.; Chatterjee, S.N. ISSR profiling of Indian cultivars of mulberry (Morus spp.) and its relevance to breeding programs. Euphytica 2003, 131, 53-63. [CrossRef]

27. Noor Camellia, N.A.; Lee, A.T.; Abdullah, N.A.P. Genetic relationships and diversity of Jatropha curcas accessions in Malaysia. Afr. J. Biotechnol. 2012, 11, 3048-3054. [CrossRef]

28. Chowdhury, M.A.; Vandenberg, B.; Warkentin, T. Cultivar identification and genetic relationship among selected breeding lines and cultivars in chickpea (Cicer arietinum L.). Euphytica 2002, 127, 317-325. [CrossRef]

29. Mahar, K.S.; Rana, T.S.; Ranade, S.A.; Meena, B. Genetic variability and population structure in Sapindus emarginatus Vahl from India. Gene 2011, 485, 32-39. [CrossRef]

30. Ganie, S.H.; Upadhyay, P.; Das, S.; Prasad Sharma, M. Authentication of medicinal plants by DNA markers. Plant Gene 2015, 4 , 83-99. [CrossRef] [PubMed]

31. Singh, M.K.; Singh, N.B.; Thakur, S.; Naik, P.K. Molecular Evaluations of Thirty One Clones of Poplar Based on Rapd and Ssr Molecular Markers. Genetika 2014, 46, 985-1001. [CrossRef] 
32. Patel, H.K.; Fougat, R.S.; Kumar, S.; Mistry, J.G.; Kumar, M. Detection of genetic variation in Ocimum species using RAPD and ISSR markers. 3 Biotech 2015, 5, 697-707. [CrossRef] [PubMed]

33. Pessina, D.; Gentili, R.; Barcaccia, G.; Nicole, S.; Rossi, G.; Barbesti, S.; Sgorbati, S. DNA content, morphometric and molecular marker analyses of Citrus limonimedica, C. limon and C. medica for the determination of their variability and genetic relationships within the genus Citrus. Sci. Hortic.-Amst. 2011, 129, 663-673. [CrossRef]

34. Onamu, R.; Solano, J.P.L.; Castellanos, J.S.; Nieto, J.P. Analysis of morphological and molecular markers in potato (Solanum tuberosum L.). Rev. Fitotec. Mex. 2012, 35, 267-277.

35. Joshi, D.C.; Shrotria, P.K.; Singh, R.; Srivastava, M.K.; Chawla, H.S. Assessment of RAPD and ISSR marker systems for establishing distinctiveness of forage Sorghum (Sorghum bicolor L. Moench) varieties as additional descriptors for plant variety protection. Indian J. Genet. Plant Breed. 2011, 71, 25-36.

36. Xu, F.; Lei, P.; Jiang, M.; Sang, L.; Guan, F.; Meng, F.; Quan, H. Genetic diversity of Herpetospermum caudigerum (Ser.) Baill using AFLP and chloroplast microsatellites. Biotechnol. Biotechnol. Equip. 2019, 33, 1260-1268. [CrossRef]

37. Powell, W.; Morgante, M.; Andre, C. The comparison of RFLP, RAPD, AFLP and SSR (microsatellite) markers for germplasm analysis. Mol. Breed. 1996, 2, 225-238. [CrossRef]

38. Titilayo, O.A.; Samuel, A.O.; David, O.O.; Adewunmi, T.I. Genetic variations among three major ethnic groups in Nigeria using RAPD. Mol. Biol. Res. Commun. 2018, 7, 51-58.

39. Dey, S.S.; Singh, A.K.; Chandel, D.; Behera, T.K. Genetic diversity of bitter gourd (Momordica charantia L.) genotypes revealed by RAPD markers and agronomic traits. Sci. Hortic.-Amst. 2006, 109, 21-28. [CrossRef]

40. Qiu, L.; Yang, C.; Tian, B.; Yang, J.B.; Liu, A. Exploiting EST databases for the development and characterization of EST-SSR markers in castor bean (Ricinus communis L.). BMC Plant Biol. 2010, 10, 278. [CrossRef]

41. Ribeiro, P.R.; de Castro, R.D.; Fernandez, L.G. Chemical constituents of the oilseed crop Ricinus communis and their pharmacological activities: A review. Ind. Crop. Prod. 2016, 91, 358-376. [CrossRef]

42. Hajrah, N.H.; Abdul, W.M.; Al-Garni, S.M.; Sheikh, A.; Ahmed, M.M.M.; Hall, N.; Saini, K.S.; Mohammad Sabir, J.S.; Bora, R.S. Gene expression profiling to elucidate the pharmacological and toxicological effects of Ricinus communis L. leaf extract in mammalian cells. Biotechnol. Biotechnol. Equip. 2019, 33, 397-407. [CrossRef]

43. Chen, L.Q.; Lu, D.F.; Chen, Z.Y. Study on wild Chimonanthus praecox in Hubei province. J. Chin. Landsc. Arch. 1990, 6, 24-26.

44. Patel, M.P.; Parmar, D.J.; Kalola, A.D.; Kumar, S. Morphological and molecular diversity patterns in castor germplasm accessions. Ind. Crop. Prod. 2017, 97, 316-323.

45. Kushwah, P.; Singh, K.P. Morphological variation in castor (Ricinus communis L.). Int. J. Inst. Pharm. Life Sci. Space Res. 2012, 2, 128-134.

46. Tripathi, N.; Chouhan, D.S.; Saini, N.; Tiwari, S. Assessment of genetic variations among highly endangered medicinal plant Bacopa monnieri (L.) from Central India using RAPD and ISSR analysis. 3 Biotech 2012, 2, 327-336. [CrossRef]

47. Luo, Q.; Ma, D.; Wang, Y. ISSR Identification of genetic diversity in Aconitum carmichaeli. Chin. Tradit. Herb. Drugs 2006, 37, 1554-1557.

48. Zhao, F.; Nie, J.; Chen, M.; Wu, G. Assessment of genetic characteristics of Aconitum germplasms in Xinjiang Province (China) by RAPD and ISSR markers. Biotechnol. Biotechnol. Equip. 2015, 29, 309-314. [CrossRef]

49. Jing, Z.B.; Wang, X.P. Genetic relationship between Chinese wild Vitis species and American and European Cultivars based on ISSR markers. Biochem. Syst. Ecol. 2013, 46, 120-126. [CrossRef]

50. PCRRAPD. Genetic diversity analysis of Morchella sp.by RAPD. Mol. Biol. Res. Commun. 2017, 6, $27-31$.

51. Gajera, B.B.; Kumar, N.; Singh, A.S.; Punvar, B.S.; Ravikiran, R.; Subhash, N.; Jadeja, G.C. Assessment of genetic diversity in castor (Ricinus communis L.) using RAPD and ISSR markers. Ind. Crop. Prod. 2010, 32, 491-498. [CrossRef]

52. Rukam, S.T.; Parakhia, M.V.; Kavani, R.H.; Dobariya, K.L.; Thakkar, J.R.; Rathod, V.M.; Dhingani, R.M.; Golakiya, B.A. Characterization of castor (Ricinus communis L.) genotypes using different markers. Res. J. Biotechnol. 2014, 9, 6-13.

53. Kanti, M.; Anjani, K.; Kiran, B.U.; Vivekananda, K. Agro-morphological and Molecular Diversity in Castor (Ricinus communis L.) Germplasm Collected from Andaman and Nicobar Islands, India. Czech J. Genet. Plant Breed. 2015, 51, 96-109. [CrossRef]

54. Foster, J.T.; Allan, G.J.; Chan, A.P.; Rabinowicz, P.D.; Ravel, J.; Jackson, P.J.; Keim, P. Single nucleotide polymorphisms for assessing genetic diversity in castor bean (Ricinus communis). BMC Plant Biol. 2010, 10, 13. [CrossRef] [PubMed] 